\title{
Population-based patterns of treatment and survival for patients with stage I and II non-small cell lung cancer aged 65-74 years and 75 years or older
}

Citation for published version (APA):

Driessen, E., Detillon, D., Bootsma, G., De Ruysscher, D., Veen, E., Aarts, M., \& Janssen-Heijnen, M. (2019). Population-based patterns of treatment and survival for patients with stage I and II non-small cell lung cancer aged 65-74 years and 75 years or older. Journal of Geriatric Oncology, 10(4), 547-554. https://doi.org/10.1016/j.jgo.2019.03.001

Document status and date:

Published: 01/07/2019

DOI:

10.1016/j.jgo.2019.03.001

Document Version:

Publisher's PDF, also known as Version of record

\section{Document license:}

Taverne

Please check the document version of this publication:

- A submitted manuscript is the version of the article upon submission and before peer-review. There can be important differences between the submitted version and the official published version of record.

People interested in the research are advised to contact the author for the final version of the publication, or visit the DOI to the publisher's website.

- The final author version and the galley proof are versions of the publication after peer review.

- The final published version features the final layout of the paper including the volume, issue and page numbers.

Link to publication

\footnotetext{
General rights rights.

- You may freely distribute the URL identifying the publication in the public portal. please follow below link for the End User Agreement:

www.umlib.nl/taverne-license

Take down policy

If you believe that this document breaches copyright please contact us at:

repository@maastrichtuniversity.nl

providing details and we will investigate your claim.
}

Copyright and moral rights for the publications made accessible in the public portal are retained by the authors and/or other copyright owners and it is a condition of accessing publications that users recognise and abide by the legal requirements associated with these

- Users may download and print one copy of any publication from the public portal for the purpose of private study or research.

- You may not further distribute the material or use it for any profit-making activity or commercial gain

If the publication is distributed under the terms of Article $25 \mathrm{fa}$ of the Dutch Copyright Act, indicated by the "Taverne" license above, 


\title{
Population-based patterns of treatment and survival for patients with stage I and II non-small cell lung cancer aged 65-74 years and 75 years or older
}

\author{
Elisabeth Driessen a,b,*, Deniece Detillon ${ }^{\mathrm{c}}$, Gerbern Bootsma ${ }^{\mathrm{d}}$, Dirk De Ruysscher ${ }^{\mathrm{e}}$, Eelco Veen ${ }^{\mathrm{c}}$, \\ Mieke Aarts ${ }^{\mathrm{f}}$, Maryska Janssen-Heijnen ${ }^{\mathrm{a}, \mathrm{b}}$ \\ a Department of Clinical Epidemiology, VieCuri Medical Centre, Venlo, the Netherlands \\ ${ }^{\mathrm{b}}$ Department of Epidemiology, Maastricht University Medical Centre +, GROW School for Oncology and Developmental Biology, Maastricht, the Netherlands \\ c Department of Surgery, Amphia Hospital, Breda, the Netherlands \\ d Department of Pulmonology, Zuyderland Medical Centre, Heerlen, the Netherlands \\ e Department of Radiation Oncology (MAASTRO Clinic), GROW School for Oncology and Developmental Biology, Maastricht University Medical Centre, Maastricht, the Netherlands \\ ${ }^{\mathrm{f}}$ Netherlands Cancer Registry, Netherlands Comprehensive Cancer Organization, Utrecht, the Netherlands
}

\section{A R T I C L E I N F O}

\section{Article history:}

Received 9 November 2018

Received in revised form 24 January 2019

Accepted 1 March 2019

Available online 12 March 2019

\section{Keywords:}

Non-small cell lung cancer

Early stage

Stage I

Stage II

Survival

Surgery

Radiotherapy

SBRT

Older patient

\begin{abstract}
A B S T R A C T
Objectives: Insights regarding utilization and survival of surgery and radiotherapy (stereotactic body radiotherapy (SBRT) or conventional radiotherapy (RT)) are lacking for older patients with stage I and II non-small cell lung cancer (NSCLC) in clinical practice.

Methods: Data from the Netherlands Cancer Registry were retrieved for patients $\geq 65$ years with clinical stage I-II NSCLC in 2010-2015. Descriptive analyses, overall survival (OS), and cox regression were stratified for stage I $(n=8742)$ and II $(n=3439)$ and compared age groups ( $65-74$ years vs $\geq 75$ years).

Results: Patients aged 65-74 underwent surgery significantly more often compared to those aged $\geq 75$ (stage I $55 \%$ vs $27 \%$; stage II: $65 \%$ vs $35 \%$ ), and received SBRT less often (I: $29 \%$ vs $42 \%$; II: $5 \%$ vs $11 \%$ ), conventional RT less often (I: $6 \%$ vs $11 \%$; II $10 \%$ vs $24 \%$ ) and best supportive care alone less often (BSC, I: $8 \%$ vs $19 \%$; II: $9 \%$ vs $25 \%$ ). One-year OS was significantly higher in patients aged $65-74$ compared to those aged $\geq 75$ (I: $87 \%$ vs $78 \%$; II: $74 \%$ vs $60 \%$ ); as was five-year OS (I: $49 \%$ vs $31 \%$; II: $36 \%$ vs $18 \%$ ). After adjustment for gender, histology, stage, treatment, and comorbidity, hazard ratio (HR) of death was higher for patients aged $\geq 75$ compared to those aged 65-74 (I: HR 1.3, 95\% confidence interval (CI) 1.1-1.5; II: HR 1.3 95\%CI 1.1-1.7).

Conclusion: Patients aged $\geq 75$ with stage I-II NSCLC had poorer OS, underwent surgery less often, and received SBRT, conventional RT, and BSC more often than patients aged 65-74. In both stages, one-year OS within age groups was similar for surgery and SBRT. However, long-term OS adjusted for prognostic factors was superior for surgery compared to SBRT and remained poorer for those aged $\geq 75$. Prospective research should focus on predictive characteristics for treatment selection and patient-centered outcomes.
\end{abstract}

(c) 2019 Elsevier Ltd. All rights reserved.
Abbreviations: BSC, Best Supportive Care; CCMO, Central Committee on Research involving Human Subjects; CI, Confidence Interval; CVA, Cerebral Vascular Accident; DM, Diabetes Mellitus; HR, Hazard Ratio; ICD-O, International Classification of Disease for Oncology; NSCLC, non-small cell lung cancer; OS, Overall Survival; RT, Radiotherapy; SBRT, Stereotactic Body RadioTherapy; TNM, Tumor Node Metastases; VATS, Video Assisted Thoracic Surgery.

* Corresponding author at: P.O. Box 1926, 5900 BX, Venlo, the Netherlands.

E-mail addresses: lizzy_driessen@hotmail.com (E. Driessen),DDetillon@amphia.nl (D. Detillon), g.bootsma@zuyderland.nl (G. Bootsma), dirk.deruysscher@maastro.nl (D. De Ruysscher), EVeen@amphia.nl (E. Veen), m.aarts@iknl.nl (M. Aarts), mjanssenheijnen@viecuri.nl (M. Janssen-Heijnen).

\section{Introduction}

Non-small cell lung cancer (NSCLC) is often diagnosed in older patients, as $65 \%$ of patients are $\geq 65$ years and one in four patients is $\geq 75$ years [1]. For stage I and II NSCLC, surgery by video-assisted thoracic surgery (VATS) or thoracotomy is considered standard treatment among patients with potentially resectable disease. Patients who are not willing to accept surgery-related risks or who are inoperable could be offered curative radiotherapy (RT) with Stereotactic Body Radiotherapy (SBRT) or hypofractionated high-dose RT. [2,3] Five-year relative survival rates for patients with stage I and II NSCLC $\geq 70$ years are $54 \%$ and $32 \%$, respectively [4].

Surgery is associated with superior survival outcomes in clinical trials including predominantly relatively young and fit patients [4]. With 
the introduction of SBRT, especially older patients and high-risk surgical candidates can receive curative-intent treatment as well [5], with local control rates of $90 \%$ after five years [6]. Recent findings indicate similar results between surgery and SBRT for operable patients [7]. Moreover, a large cohort from the National Cancer Database in the United states covering 84,839 patients with early stage NSCLC, found that the 30 -day and 90-day mortality was significantly higher after surgery compared to SBRT, especially among patients aged $\geq 66$ years [8]. Data from the Dutch Lung Surgery Audit in the Netherlands indicated that operative mortality is higher among octogenarians with NSCLC compared to patients aged 60-79 years, while the incidence of complications was similar [9]. Several factors correlate with poorer treatment tolerance and survival, such as higher age [10], comorbidity, poorer physical performance [9,11], and larger extent of resection [9,12]. Also, clinical trials state strict eligibility criteria for inclusion regarding performance status, age, and level of organ function in order to minimize the risk of complications [13]. As a result, evidence regarding outcomes of treatment is scarce for older and vulnerable patients [12]. Insights regarding treatment patterns and survival within the older adult population are highly needed in daily clinical practice. As this evidence is currently lacking, our study compares treatment patterns and overall survival (OS) for patients aged $65-74$ years and those aged $\geq 75$ years with clinical stage I and II NSCLC in daily clinical practice in the Netherlands.

\section{Methods}

All patients aged $\geq 65$ years diagnosed with clinical stage I or II NSCLC during 2010-2015 were retrieved from the population-based Netherlands Cancer Registry, which is maintained by the Netherlands Comprehensive Cancer Organization (Fig. 1). Trained registrars have routinely collected data from medical records regarding patient and tumor characteristics of all newly diagnosed patients with cancer in the Netherlands since 1989. Vital status was retrieved from the nationwide population registries network with complete follow-up until February 1st 2018. This study was approved by the Privacy Review Board of the Netherlands Cancer Registry. The Central Committee on Research involving Human Subjects (CCMO) judged that approval of an ethics committee was not required.

The International Classification of Disease for Oncology (ICD-O3) [14] code for pulmonary tumors (C34) was used at the Netherlands
Comprehensive Cancer Organization in order to include all patients with NSCLC as well as clinical diagnoses [15]. Patients with other histologies were excluded. Age (65-74 years and $\geq 75$ years), gender, histology, and clinical stage were retrieved. Stage of disease was classified according to clinical Tumor Node Metastases (TNM) edition 7 [16]. In Dutch staging guidelines, it is stated that all patients suspected for NSCLC should be staged by PET-CT scan. When the PET-CT scan is positive, lymph nodes are enlarged, and the patient is fit enough, mediastinal staging by EUS/EBUS will be applied [2,17]. For patients without histologic confirmation of the tumor, TNM classification was registered since 2011. A small proportion diagnosed in 2010 did not have a histologic confirmation. In order to classify these patients into stage groups, trends in stage distributions between 2011 and 2015 were compared to those in 2010. In 2011-2015, the increase of patients with stage I NSCLC was similar to the proportion of patients without histologic confirmation in 2010. Therefore, it was decided to classify this group diagnosed in 2010 as stage I NSCLC. Information on comorbidity was available for patients in the southeastern part of the Netherlands only, covering approximately $18 \%$ of included patients. Comorbidity was registered according to a slightly adapted version of the Charlson Comorbidity Index (CCI) [18] at the Netherlands Comprehensive Cancer Organization. Retrieved comorbidity data were classified as number of comorbid conditions $(0,1$, or $\geq 2)$, and type of comorbidity (respiratory, cardiovascular, digestive, hypertension, diabetes mellitus (DM), previous malignancy, or cerebrovascular accident (CVA)/hemiplegia). Treatment was categorized as VATS, thoracotomy, SBRT (3-8 fractions), conventional RT, chemotherapy, chemoradiotherapy (chemotherapy and radiotherapy within 90 days of each other), and Best Supportive Care (BSC).

\subsection{Statistical Analyses}

Statistical analyses were performed using IBM SPSS Statistics 24.0. All analyses were stratified for stage of disease (I and II) and age groups. Descriptive statistics and OS were compared between age groups (6574 years and $\geq 75$ years) and differences were assessed for significance by the $X^{2}$-test for categorical variables and the Mann-whitney $U$ test for continuous variables $(P<.05$ two sided). Results were displayed as number (percentage) or median (interquartile range (IQR)). As chemotherapy and chemoradiotherapy covered only small proportions and

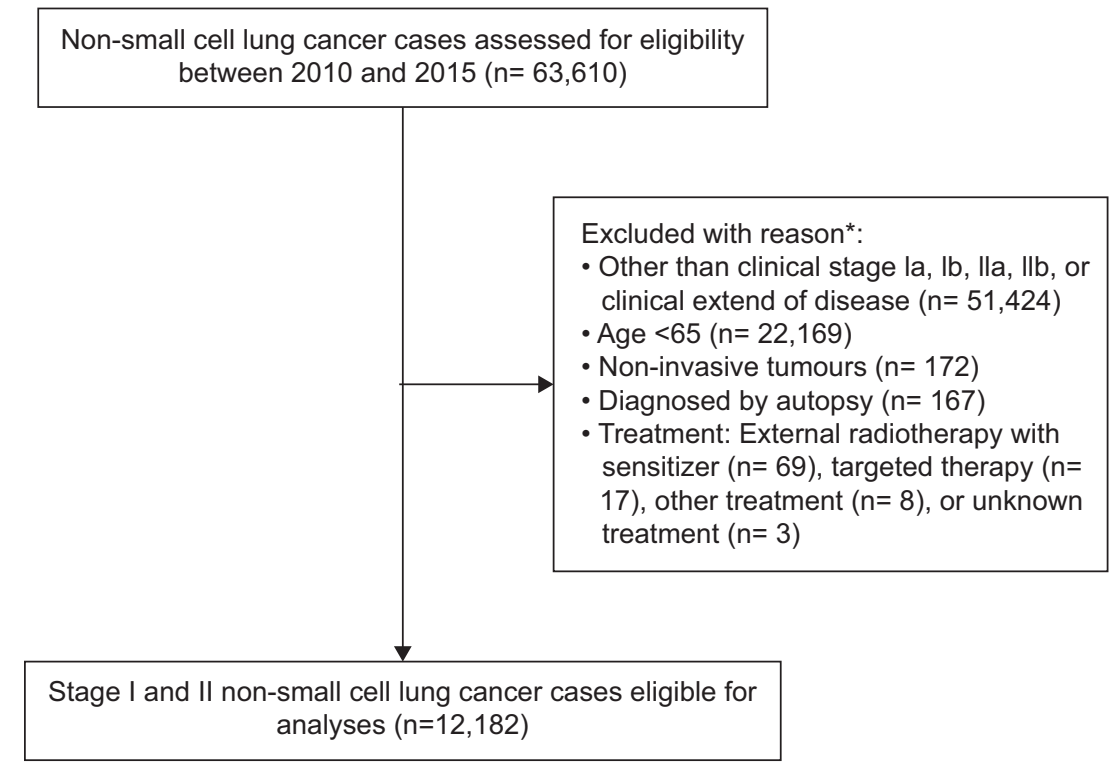

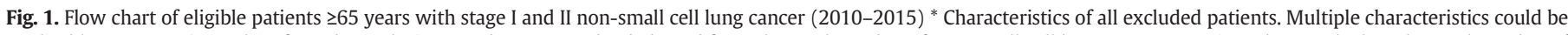

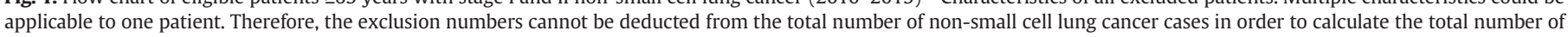
eligible cases. 
are not considered regular treatment options for stage I-II NSCLC [2], these were excluded from survival analyses. OS rates were calculated from the date of diagnosis until death or until February 1st 2018 by median, one-year, and five-year OS, and were visualised by the Kaplan-Meier method. Median follow-up was estimated with the reverse Kaplan-Meier method [19]. Hazard Ratios (HRs) for mortality were calculated by Cox proportional hazard regression analyses. HRs were adjusted for factors affecting survival based on previous studies and included in model 1: utilized treatment [7], gender [20], age $[4,9,10]$, stage [21], and histology [22]. In subanalyses, the cohort of the southeastern part of the Netherlands was used to investigate whether number of comorbid conditions [23] was an independent predictive factor for mortality as well, and was added in model 2. Imputation of missing values for comorbidity was not performed for patients outside the southeastern part of the Netherlands, as approximately $80 \%$ of outcomes would be imputed. Both OS rates and HRs were displayed with corresponding 95\% confidence intervals (95\%CI). HR $>1.0$ indicates an increased hazard of death. The HR was considered statistically significant when the $95 \% \mathrm{CI}$ was completely above or below 1.0.

\section{Results}

In the Netherlands, 12,182 patients aged $\geq 65$ years were diagnosed with stage I-II NSCLC between 2010 and 2015 (Fig. 1), covering 19\% of all primary cases of lung cancer. Over half of the study population was aged $65-74$ years (53\%, Table 1 ). For stage I NSCLC, patients aged 6574 years underwent VATS ( $32 \%$ vs $16 \%$ ) and thoracotomy ( $23 \%$ vs $11 \%$ ) significantly more often, while SBRT ( $29 \%$ vs $42 \%$ ), conventional
RT (6\% vs $11 \%$ ), and BSC ( $8 \%$ vs $19 \%$ ) were utilized significantly less often compared to those aged $\geq 75$ years. Two or more comorbid conditions were less often present among patients aged $65-74$ years (66\%) compared to those aged $\geq 75$ years ( $73 \%$ ), whereas $26 \%$ and $23 \%$ suffered from one comorbid condition, respectively. Patients aged $\geq 75$ years suffered more often from $\mathrm{DM}(p=.001)$, previous malignancy $(p=.02)$, and CVA or hemiplegia $(p=.004)$ compared to patients aged 6574 years. For stage II NSCLC, patients aged 65-74 years underwent VATS significantly more often ( $25 \%$ vs $13 \%$ ), as well as thoracotomy ( $40 \%$ vs $22 \%$ ), and chemoradiotherapy ( $9 \%$ vs $5 \%$ ), while SBRT ( $5 \%$ vs $11 \%$ ), conventional RT ( $10 \%$ vs $24 \%$ ), and BSC ( $9 \%$ vs $25 \%$ ) were utilized significantly less often compared to those aged $\geq 75$ years. Proportions of the number and type of comorbid conditions were comparable between age groups.

Median follow-up was 58 months (95\%CI 57-59 months). Fig. 2a and $\mathrm{b}$ display that within age and stage groups, OS seemed similar until one year for VATS, thoracotomy, and SBRT. However, survival curves were declining more rapidly after one year among those aged $\geq 75$. After two years, both surgical approaches indicated superior OS compared to SBRT and conventional RT among patients aged 6574 years for both stages, and among those aged $\geq 75$ years for stage I NSCLC only. Furthermore, SBRT showed superior OS compared to conventional RT. For patients aged $\geq 75$ specifically, VATS showed superior survival after two years in both stages as compared to other treatment options. For stage I, this is consecutively followed by thoracotomy and SBRT. For those aged $\geq 75$ years with stage II NSCLC, OS was similar up until two years for VATS and SBRT and superior with respect to other treatment options, while OS for SBRT and thoracotomy were similar and lower compared to VATS after 3 years.

Table 1

Overview of patient and tumor characteristics of older patients with stage I-II non-small cell lung cancer (2010-2015) according to stage and age groups.

\begin{tabular}{|c|c|c|c|c|c|c|}
\hline \multirow{3}{*}{$\begin{array}{l}\text { Stage } \\
\text { Age years } \\
n(\%)\end{array}$} & \multicolumn{3}{|l|}{ I } & \multicolumn{3}{|l|}{ II } \\
\hline & $65-74$ & $\geq 75$ & P-value & $65-74$ & $\geq 75$ & P-value \\
\hline & $4694(54)$ & $4048(46)$ & & $1774(52)$ & $1665(49)$ & \\
\hline Median age years (IQR) & $69(67-72)$ & $79(77-82)$ & $<0.01^{\mathrm{a}}$ & $69(67-72)$ & $79(77-83)$ & $<0.01^{\mathrm{a}}$ \\
\hline Gender Male \% & 59 & 65 & $<0.01^{\mathrm{a}}$ & 66 & 75 & $<0.01^{\mathrm{a}}$ \\
\hline Histology \% & & & $<0.01^{\mathrm{a}}$ & & & $<0.01^{\mathrm{a}}$ \\
\hline Squamous CC & 31 & 27 & & 48 & 51 & \\
\hline Adenocarcinoma & 41 & 27 & & 36 & 22 & \\
\hline NOS/ large CC & 28 & 46 & & 17 & 27 & \\
\hline Stage $\%$ & & & $0.01^{\mathrm{a}}$ & & & 0.30 \\
\hline A & 68 & 66 & & 46 & 48 & \\
\hline $\mathrm{B}$ & 32 & 34 & & 54 & 52 & \\
\hline Treatment\% & & & $<0.01^{\mathrm{a}}$ & & & $<0.01^{\mathrm{a}}$ \\
\hline VATS & 32 & 16 & & 25 & 13 & \\
\hline Thoracotomy & 23 & 11 & & 40 & 22 & \\
\hline SBRT & 29 & 42 & & 5 & 11 & \\
\hline Conventional RT & 6 & 11 & & 10 & 24 & \\
\hline Chemotherapy & 1 & 0,5 & & 3 & 2 & \\
\hline Chemoradiotherapy & 1 & 0,5 & & 9 & 5 & \\
\hline BSC & 8 & 19 & & 9 & 25 & \\
\hline \multicolumn{7}{|l|}{ Comorbidity $^{\mathrm{b}}$} \\
\hline Available n (\%) & $866(18)$ & 709 (18) & & $332(19)$ & $300(18)$ & \\
\hline Number \% & & & $0.002^{\mathrm{a}}$ & & & 0.42 \\
\hline 0 & 8 & 4 & & 13 & 10 & \\
\hline 1 & 26 & 23 & & 24 & 23 & \\
\hline$\geq 2$ & 66 & 73 & & 63 & 67 & \\
\hline \multicolumn{7}{|l|}{ Type \% } \\
\hline Respiratory & 45 & 41 & 0.06 & 34 & 34 & 0.99 \\
\hline Cardiovascular & 51 & 58 & 0.06 & 50 & 54 & 0.24 \\
\hline Hypertension & 36 & 38 & 0.55 & 34 & 41 & 0.08 \\
\hline DM & 14 & 21 & 0.001 & 15 & 19 & 0.15 \\
\hline Previous malignancy & 36 & 42 & 0.02 & 28 & 29 & 0.92 \\
\hline CVA/hemiplegia & 5 & 8 & 0.004 & 9 & 12 & 0.28 \\
\hline Digestive & 8 & 9 & 0.76 & 9 & 7 & 0.27 \\
\hline
\end{tabular}

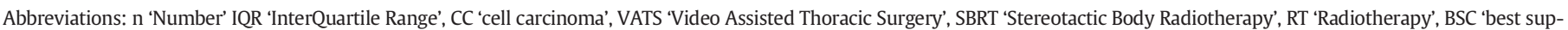
portive care', CVA 'Cerebrovascular accident', DM 'Diabetes Mellitus'.

a indicates significant differences between age groups.

b Subanalyses of 2207 patients (18\%) with available information on comorbidity. 
A

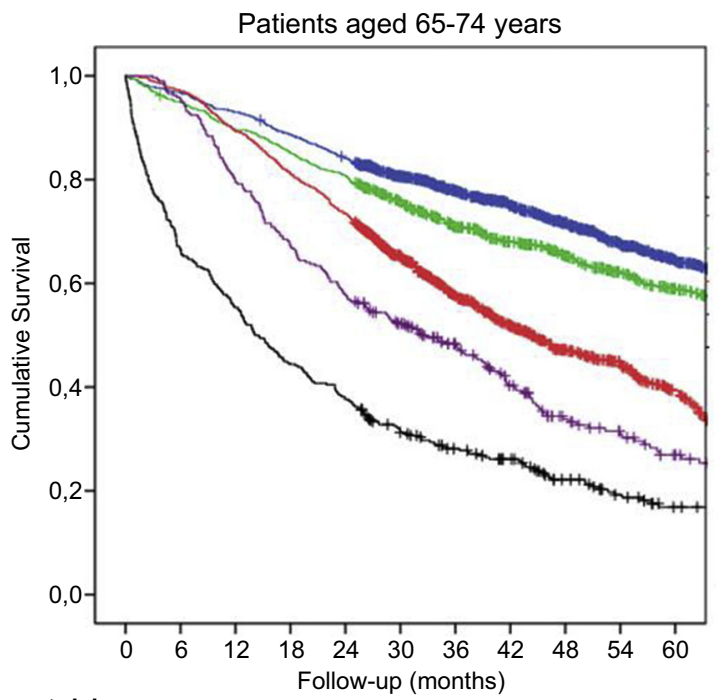

Number at risk

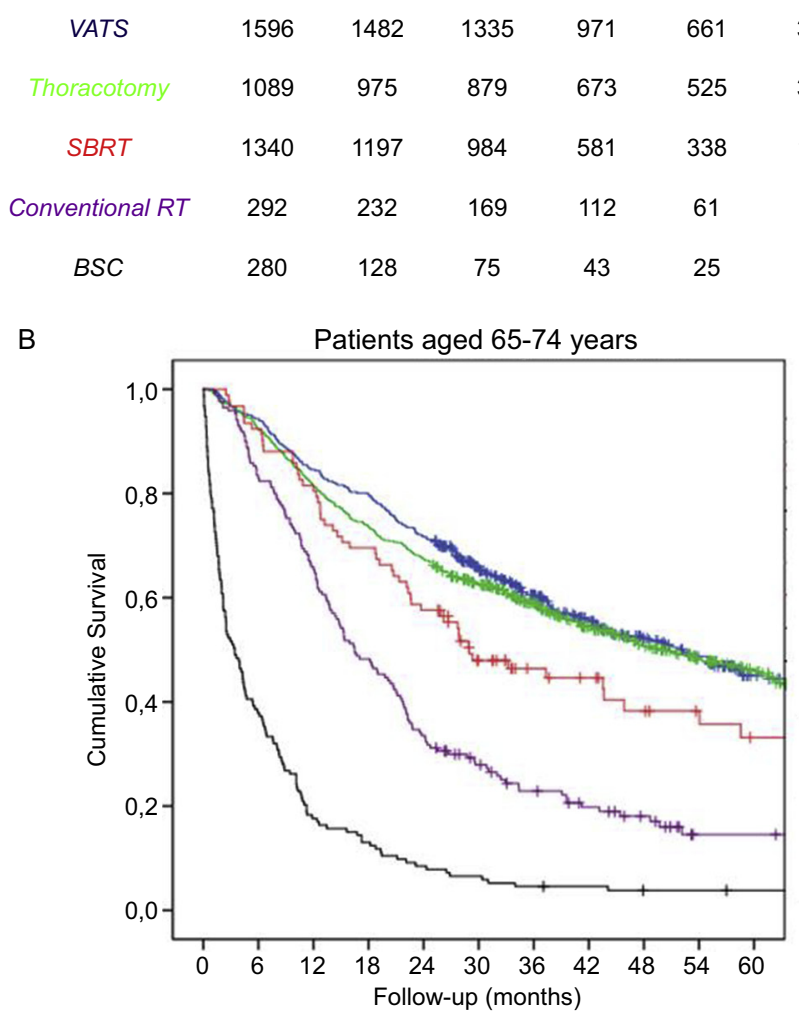

Number at risk

\begin{tabular}{|c|c|c|c|c|c|c|c|c|c|c|c|}
\hline VATS & 445 & 376 & 319 & 205 & 128 & 69 & 211 & 170 & 137 & 88 & 50 \\
\hline Thoracotomy & 703 & 572 & 474 & 349 & 246 & 178 & 362 & 275 & 199 & 130 & 99 \\
\hline SBRT & 92 & 74 & 53 & 26 & 18 & 15 & 179 & 146 & 105 & 56 & 32 \\
\hline Conventional $R T$ & 170 & 112 & 57 & 31 & 18 & 8 & 391 & 222 & 109 & 57 & 31 \\
\hline$B S C$ & 149 & 24 & 10 & 6 & 4 & 3 & 409 & 103 & 35 & 11 & 4 \\
\hline
\end{tabular}

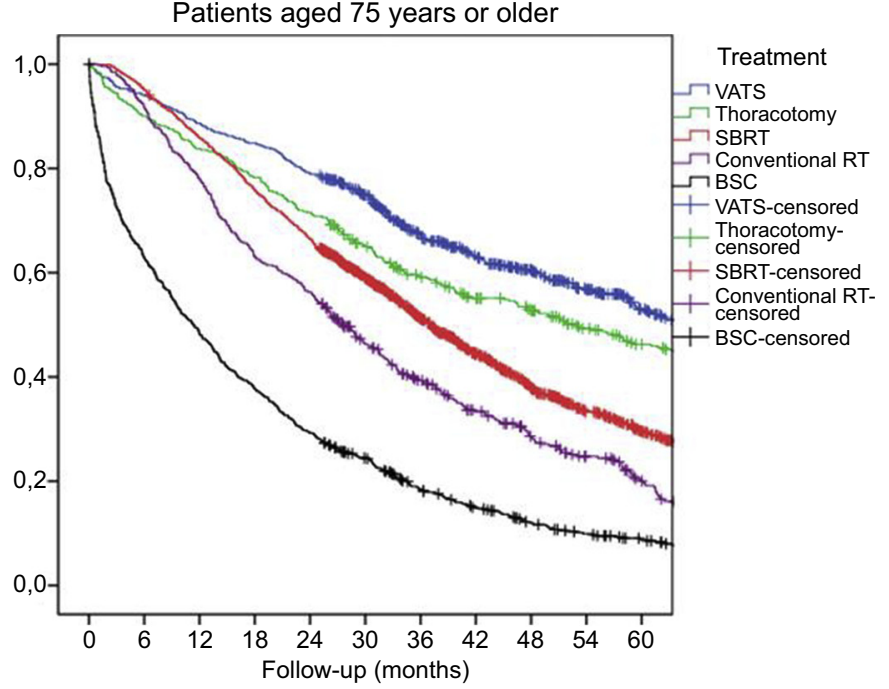

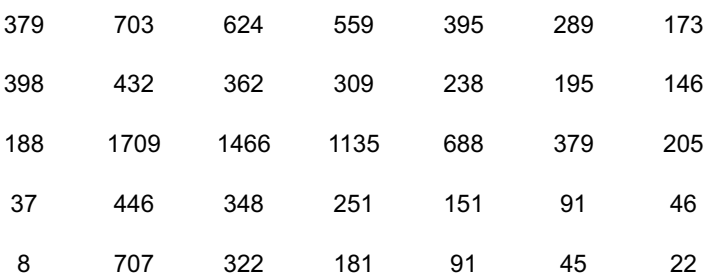

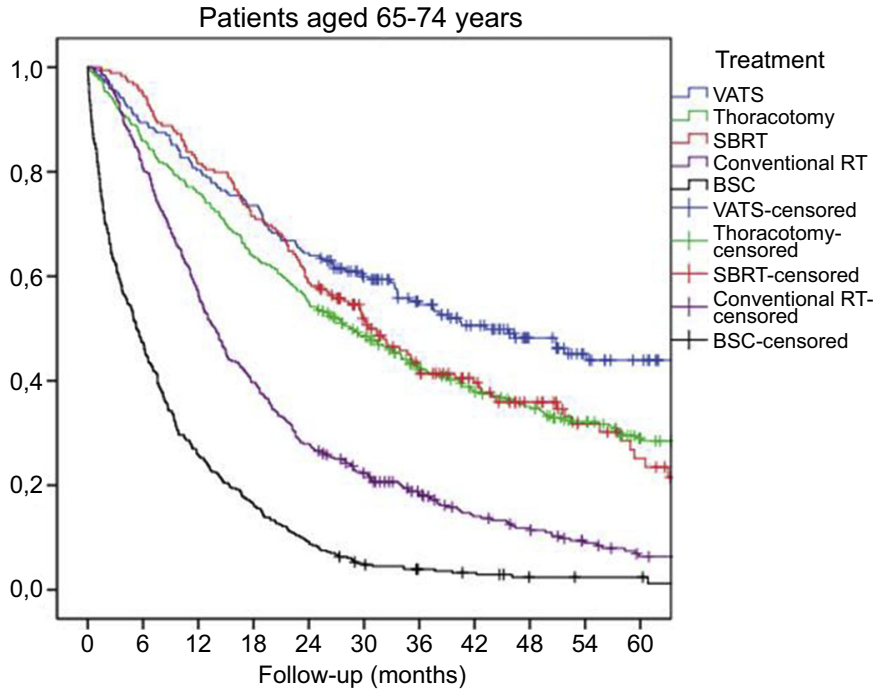

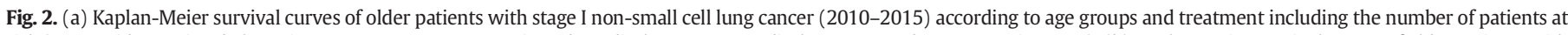

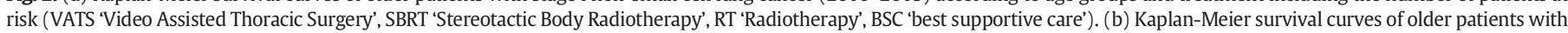

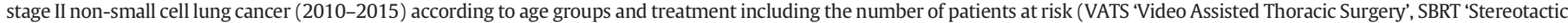
Body Radiotherapy', RT 'Radiotherapy', BSC 'best supportive care').

One-year and five-year OS rates were displayed in Table 2. For stage I NSCLC, these OS rates were significantly higher for patients aged 6574 years ( $87 \%$ and $49 \%$, respectively) compared to those aged $\geq 75$ years ( $78 \%$ and $31 \%$, respectively). After stratification of treatment, both one-year and five-year OS rates were significantly higher for patients aged $65-74$ years compared to those aged $\geq 75$ years for all 
Table 2

Overall survival rates and median overall survival of older patients with stage I-II non-small cell lung cancer (2010-2015) according to stage, age groups, and treatment.

\begin{tabular}{|c|c|c|c|c|}
\hline \multirow{2}{*}{$\begin{array}{l}\text { Stage } \\
\text { Age years }\end{array}$} & \multicolumn{2}{|l|}{ I } & \multicolumn{2}{|l|}{ II } \\
\hline & $65-74$ & $\geq 75$ & $65-74$ & $\geq 75$ \\
\hline 1-year OS \% (95\%CI) Treatment & $87(86-88)^{a}$ & $78(77-79)^{\mathrm{a}}$ & $74(72-76)^{\mathrm{a}}$ & $60(57-62)^{a}$ \\
\hline VATS & $93(92-94)^{a}$ & $89(86-91)^{a}$ & $85(81-88)$ & $80(75-86)$ \\
\hline Thoracotomy & $90(88-91)^{\mathrm{a}}$ & $84(80-87)^{\mathrm{a}}$ & $81(78-84)$ & $76(72-80)$ \\
\hline SBRT & $89(88-91)^{a}$ & $86(84-87)^{a}$ & $80(72-89)$ & $82(76-87)$ \\
\hline Conventional RT & $79(75-84)$ & $78(74-82)$ & $66(59-73)$ & $57(52-62)$ \\
\hline BSC & $55(50-61)^{a}$ & $45(42-49)^{\mathrm{a}}$ & $18(12-24)$ & $25(22-30)$ \\
\hline 5-year OS \% (95\%CI) & $49(48-51)^{\mathrm{a}}$ & $31(29-32)^{a}$ & $36(34-39)^{a}$ & $18(16-20)^{\mathrm{a}}$ \\
\hline \multicolumn{5}{|l|}{ Treatment } \\
\hline VATS & $64(62-67)^{a}$ & $53(49-58)^{\mathrm{a}}$ & $45(39-50)$ & $43(36-51)$ \\
\hline Thoracotomy & $59(56-62)^{\mathrm{a}}$ & $46(42-51)^{a}$ & $46(42-50)^{a}$ & $29(24-34)^{\mathrm{a}}$ \\
\hline SBRT & $40(36-43)^{a}$ & $30(27-33)^{a}$ & $33(22-45)$ & $27(19-36)$ \\
\hline Conventional RT & $27(21-33)$ & $20(16-25)$ & $14(8.2-21)$ & $6.7(3.7-9.6)$ \\
\hline BSC & $17(12-21)^{a}$ & $8.8(6.5-11)^{a}$ & $3.8(0.7-6.9)$ & $2.3(0.7-3.9)$ \\
\hline Median OS months (95\%CI) Treatment & $60(57-63)^{a}$ & $33(32-35)^{\mathrm{a}}$ & $35(31-38)^{a}$ & $17(15-18)^{a}$ \\
\hline VATS & $83(76-91)^{a}$ & $65(57-73)^{a}$ & $52(43-61)$ & $43(31-56)$ \\
\hline Thoracotomy & $82(75-90)^{a}$ & $53(42-64)^{\mathrm{a}}$ & $50(42-58)^{\mathrm{a}}$ & $29(24-34)^{a}$ \\
\hline SBRT & $44(40-48)^{\mathrm{a}}$ & $37(35-39)^{\mathrm{a}}$ & $29(19-39)$ & $30(26-35)$ \\
\hline Conventional RT & $32(25-39)$ & $28(24-31)$ & $16(13-20)$ & $14(12-15)$ \\
\hline BSC & $14(12-17)$ & $11(9.8-13)$ & $34(2.1-4.7)$ & $5.3(4.3-6.3)$ \\
\hline
\end{tabular}

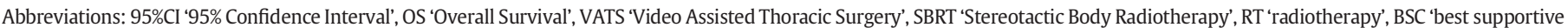
care'.

a Indicates significant differences when confidence intervals between age groups are not overlapping.

treatments. However, one-year OS was comparable between age groups for conventional RT and five-year OS were comparable for both conventional RT and SBRT. For stage II NSCLC, one-year and five-year OS rates were significantly higher for patients aged $65-74$ years ( $74 \%$ and $36 \%$, respectively) compared to those aged $\geq 75$ years ( $60 \%$ and $18 \%$, respectively, Table 2). After stratification of treatment, one-year OS was comparable between age groups for all treatment options. The five-year OS rates were significantly different between age groups for thoracotomy

Table 3

Multivariable cox proportional hazard ratios of older patients diagnosed with stage I-II non-small cell lung cancer (2010-2015) according to stage.

\begin{tabular}{|c|c|c|c|c|c|}
\hline \multirow[t]{2}{*}{ Stage } & & \multicolumn{2}{|l|}{ I } & \multicolumn{2}{|l|}{ II } \\
\hline & & HR (95\%CI) & P-value & HR (95\%CI) & P-value \\
\hline \multicolumn{6}{|l|}{ Model 1} \\
\hline \multirow[t]{2}{*}{ Age } & $65-74$ years & Reference & & Reference & $<0.01$ \\
\hline & $\geq 75$ years & $1.3(1.2-1.3)$ & $<0.01$ & $1.1(0.99-1.3)$ & \\
\hline \multirow[t]{2}{*}{ Gender } & Male & Reference & & Reference & $<0.01$ \\
\hline & Female & $0.79(0.75-0.84)$ & $<0.01$ & $0.86(0.78-0.94)$ & \\
\hline \multirow[t]{3}{*}{ Histology } & Squamous CC & Reference & & Reference & \\
\hline & Adenocarcinoma & $0.86(0.79-0.92)$ & $<0.01$ & $0.92(0.83-1.0)$ & 0.11 \\
\hline & NOS/large CC & $1.0(0.97-1.1)$ & 0.23 & $1.0(0.91-1.1)$ & 0.78 \\
\hline \multirow[t]{2}{*}{ Stage } & A & Reference & & Reference & \\
\hline & B & $1.5(1.4-1.6)$ & $<0.01$ & $0.78(0.72-0.86)$ & $<0.01$ \\
\hline \multirow[t]{5}{*}{ Treatment } & VATS & Reference & & Reference & \\
\hline & Thoracotomy & $1.1(0.98-1.2)$ & 0.13 & $1.3(1.1-1.6)$ & 0.06 \\
\hline & SBRT & $1.9(1.7-2.1)$ & $<0.01$ & $1.3(1.1-1.6)$ & 0.01 \\
\hline & Conventional RT & $2.4(2.2-2.7)$ & $<0.01$ & $2.7(2.3-3.2)$ & $<0.01$ \\
\hline & BSC & $5.0(4.5-5.5)$ & $<0.01$ & $6.6(5.7-7.7)$ & $<0.01$ \\
\hline \multicolumn{6}{|l|}{ Model $2^{a}$} \\
\hline \multirow[t]{2}{*}{ Age } & $65-74$ years & Reference & & Reference & \\
\hline & $\geq 75$ years & $1.3(1.1-1.5)$ & $<0.01$ & $1.3(1.1-1.7)$ & 0.01 \\
\hline \multirow[t]{2}{*}{ Gender } & Male & Reference & & Reference & \\
\hline & Female & $0.79(0.68-0.91)$ & $<0.01$ & $0.92(0.73-1.2)$ & 0.49 \\
\hline \multirow[t]{3}{*}{ Histology } & Squamous CC & Reference & & Reference & \\
\hline & Adenocarcinoma & $0.93(0.78-1.1)$ & 0.41 & $1.1(0.88-1.5)$ & 0.35 \\
\hline & NOS/large CC & $1.1(0.91-1.3)$ & 0.29 & $1.1(0.86-1.4)$ & 0.46 \\
\hline \multirow[t]{2}{*}{ Stage } & A & Reference & & Reference & \\
\hline & B & $1.5(1.3-1.7)$ & $<0.01$ & $0.71(0.58-0.86)$ & $<0.01$ \\
\hline \multirow[t]{5}{*}{ Treatment } & VATS & Reference & & Reference & \\
\hline & Thoracotomy & $1.2(0.92-1.5)$ & 0.23 & $0.995(0.74-1.3)$ & 0.98 \\
\hline & SBRT & $1.9(1.5-2.3)$ & $<0.01$ & $2.5(1.6-3.8)$ & $<0.01$ \\
\hline & Conventional RT & $2.6(2.0-3.4)$ & $<0.01$ & $2.8(2.0-3.9)$ & $<0.01$ \\
\hline & BSC & $4.2(3.3-5.3)$ & $<0.01$ & $7.2(5.1-10)$ & $<0.01$ \\
\hline \multirow[t]{3}{*}{ Number of comorbid conditions } & 0 & Reference & & Reference & \\
\hline & 1 & $1.3(0.93-1.8)$ & 0.13 & $0.92(0.64-1.3)$ & 0.64 \\
\hline & $\geq 2$ & $1.5(1.1-2.1)$ & 0.01 & $0.93(0.68-1.3)$ & 0.66 \\
\hline
\end{tabular}

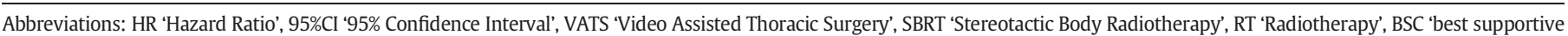
care', CC 'Cell Carcinoma', NOS 'Not Otherwise Specified'.

a Subanalyses of 2207 patients (18\%) with available information on comorbidity. 
( $46 \%$ vs $29 \%$ ) and SBRT (33\% vs $27 \%$ ), but were comparable for all other treatment options.

The adjusted HR of death are displayed in Table 3. Patients aged $\geq 75$ showed a significant 1.3-fold higher HR of death compared to those aged 65-74 years for both stages (model 2 (including comorbidity as well)). The HR of death was also significantly higher for SBRT (stage I: HR 1.9 (95\%CI 1.5-2.3); stage II: HR 2.5 (95\%CI 1.6-3.8)) and conventional RT (stage I: HR 2.6 (95\%CI 2.0-3.4); stage II: HR 2.8 (95\%CI 2.03.9)) compared to VATS, and the highest HR of death was seen for BSC (stage I: HR 4.2 (95\%CI 3.3-5.3); stage II: HR 7.2 (95\%CI 5.1-10)). For patients with stage I NSCLC, females showed a significantly decreased HR of death compared to males (HR 0.79 (95\%CI 0.68-0.91)). A significant higher HR of death was seen for patients with stage IB (HR 1.5 (95\%CI 1.3-1.7)) compared to stage IA, and for $\geq 2$ comorbid conditions (HR 1.5 (95\%CI 1.1-2.1)) compared to no comorbid conditions. For patients with stage II NSCLC, stage IIB was associated with significantly decreased HR of death compared to stage IIA (HR 0.71 (95\%CI 0.58-0.86)).

\section{Discussion}

Evidence regarding treatment options and outcomes are scarce for older patients with NSCLC and evidence-based insights are highly needed for this vulnerable population. The aim of this study was to compare treatment patterns and OS between patients aged $65-74$ years and those aged $\geq 75$ years with clinical stage I and II NSCLC in daily clinical practice. Patients aged $\geq 75$ years underwent surgery less often, and received SBRT, conventional RT, and BSC more often than patients aged 65-74 years in both stages. Superior one-year OS was seen for VATS, thoracotomy, and SBRT among patients aged 65-74 years compared to those aged $\geq 75$ years with stage I NSCLC. However, one-year OS was similar between those treatment options and both age groups among patients with stage II NSCLC. Superior long-term OS was seen for VATS and thoracotomy among both age groups with stage I NSCLC and among those aged 65-74 years with stage II NSCLC. However, superior long-term OS for patients aged $\geq 75$ years with stage II NSCLC was found after VATS. After adjustment for known prognostic factors including comorbidity, the HR of death remained significantly higher for patients aged $\geq 75$ years compared to their younger counterparts in both stage groups.

The current study found that older patients with NSCLC undergo surgery less often compared to younger patients [5]. Recently, improvements in survival after both surgery and RT have been found $[5,24]$. While SBRT is recommended for inoperable patients over non-SBRT radiotherapy techniques [2,25], the superiority of surgical resection over SBRT is debated for operable and older patients $[7,26]$. In our study, similar one-year OS rates were found for VATS and SBRT within age groups. Comparable short-term survival outcomes for surgery and RT were also found in a retrospective multicenter cohort [27], a large registration database [8], clinical trials including operable patients [7], and a metaanalysis [28]. However, long-term OS in our study was superior for VATS and thoracotomy among patients aged 65-74 years in both stages and for those aged $\geq 75$ years with stage II, whereas only VATS was superior for those aged $\geq 75$ years with stage II NSCLC. SBRT was associated with better OS compared to conventional RT in both age groups, which was also found in a meta-analysis without age-restrictions [25]. Although the adjusted HR of death for both conventional RT and SBRT were increased compared to VATS, this increase was higher for conventional RT than SBRT in our study. SBRT could be a treatment option for older adults with stage I NSCLC, as local control rates of $>90 \%$ can be achieved after five years [6], and treatment tolerance is acceptable [29]. Moreover, the safety and effectiveness of SBRT for patients aged $\geq 80$ years was previously demonstrated [30], and comparable short term survival rates were previously found for surgery and radiotherapy among patients aged $\geq 85$ years [31], which are partially represented in our dataset as well. A small proportion of patients with stage II NSCLC received SBRT. Although this treatment is not standard for stage II disease, it could be an option for specific situations and is administered to patients with tumors $>5 \mathrm{~cm}$ in the Netherlands [32]. Although, shortterm OS after SBRT within age and stage groups seemed comparable to VATS in our study, long-term outcomes remain to be in favor of surgery in both older age groups. However, SBRT should not be withheld from older patients based on stage alone and it should be kept in mind that surgical patients with long-term survival are a selected subpopulation among older patients with NSCLC and are more likely to be included in clinical trials.

Explanations for poorer OS in older patients are diverse and could depend on a combination of age $\geq 75$ years $[10,33]$, short life expectancy [34], (undiagnosed or unforeseen) lymph node metastases [35], poorer physical performance $[9,11]$, and comorbid conditions [2,9]. It was expected that pulmonary comorbid conditions would be different between age groups, impacting treatment choice among the oldest group and negatively impacting OS [9,36,37]. Differences in OS between treatment groups were significant, and it is expected that younger and fitter patients were selected for surgery compared to radiotherapy in both stages [2]. Although we were able to adjust the HR of death for the number of comorbid conditions, adjustment was not optimal as severity of comorbidity was not available. Treatment decisions could also depend on other prognostic factors than those accounted for in this study, such as performance status, cognitive status, pulmonary function, and preferences of the patient [10]. Patient involvement in treatment decision-making is important as almost half of patients with stage I-II NSCLC experience conflicts in treatment decision-making, and one in three patients feel uninformed [38]. This implies that not only patient or tumor characteristics should be taken into account to determine which treatment is the most optimal for each older individual, but patient-centered outcomes should be taken into account as well [39]. A recent study found that health utility, or summarized quality of life, was not significantly different between patients receiving surgery or SBRT for stage I NSCLC [40]. Insights regarding treatment patterns and OS in daily clinical practice would be even more valuable when associated with patient preferences and patient-centered outcomes [38]. This information could improve the treatment decision-making process for both patients and physicians and outcomes for the heterogeneous group of older patients with stage I and II NSCLC.

Strengths of this population-based study were the nationwide coverage and inclusion of unselected patients with clinical stage I-II NSCLC between 2010 and 2015 in the Netherlands. This leads to more generalized results compared to other studies including institutional data. Other strengths were the high quality standard of included data, the completeness regarding obtained treatment, and the availability of information on comorbidity in the southeastern part of the Netherlands. Furthermore, all citizens in the Netherlands have equal access and imbursement to healthcare. Altogether, this leads to the selection of (almost) all patients in the given period, and a description of treatment and survival which is not influenced by financial resources. However, some limitations should be mentioned. As this is an observational study, causal relations cannot be drawn. Dutch practice guidelines indicate that patients who present with a high-risk profile of lung cancer are suspected of stage I NSCLC based on a new or growing [18] FDG-PET positive lesion. These patients are diagnosed with a primary (stage I) lung tumor [41]. Information regarding treatment choice, performance status, radiation dose, hospitalization, completion of treatment, pulmonary function, and adverse events was unavailable. Information on comorbidity was known for $18 \%$ of patients. Nevertheless, valuable insights have been gained regarding treatment, OS, and adjusted risks of death for both older age groups and stages. Despite a median follow-up of 58 months, five-year OS rates could have been slightly higher if a longer follow-up period could have been taken into account. The fairly large difference in OS between SBRT and conventional RT could be explained by some patients receiving palliative doses of conventional RT. Unfortunately, information on palliative or curative doses was not available. Also, some tumors can only be treated 
with SBRT due to the location and risk of surgery related complications. Furthermore, confounding by indication should be considered, as treatment choice in clinical practice partially depends on patient characteristics such as comorbid conditions. Also, therapeutic nihilism is of significant importance for the interpretation of treatment patterns and outcomes among older patients, as it can be thought that (standard) treatment would be more harmful than beneficial.

Since clinical trials including older patients often suffer from slow accrual and restrictions regarding age, performance and cognitive status and comorbid conditions, large nation-wide cohort studies including big data collection including treatment selection, and patient centered outcomes can help with generalizability and treatment decision making [42]. Also, wishes and expectations of both patients and caregivers should have a more prominent role in the treatment-decision process to gain the most optimal and personal treatment decision [38,43]. Altogether, evidence can be gained for the heterogeneous population with often vulnerable and frail older patients who are not always fit for surgery, in the light of the best evidence, clinician's expertise, and preferences of patients and caregivers.

\subsection{Conclusion}

Patients aged $\geq 75$ years with stage I and II NSCLC underwent surgery less often than those aged 65-74 years and had poorer OS, even after adjustment for other known prognostic factors. In both stages, oneyear OS within age groups was similar for surgery and SBRT. However, adjusted long-term OS was superior for surgery compared to SBRT and remained poorer for those aged $\geq 75$. These findings could form the basis for impactful trials as older patients cannot be compared based on age alone. The perspectives regarding treatment and survival for this heterogeneous and vulnerable group of older patients with stage I-II NSCLC should be optimized by prospective research focusing on predictive patient characteristics for treatment selection and patient-centered outcomes such as complications and quality of life with respect to survival.

\section{Conflicts of Interest}

Prof. Dr. D de Ruysscher previously received research grants and fees. These were gained by the institution for previous research and not personally. Other (co-)authors did not declare conflicts of interest. This research did not receive any specific grant from funding agencies in the public, commercial, or not-for-profit sectors.

\section{Authorship contributions}

Specific contributions to different parts of the manuscript were as follows:

- Study concepts: Ms. Driessen, Mrs. Janssen-Heijnen, and Mrs. Aarts

- Study design: Ms. Driessen and Mrs. Janssen-Heijnen

- Data acquisition: Data managers of the Netherlands Comprehensive Cancer Organization

- Quality control of data and algorithms: Ms. Driessen, Mrs. Aarts, Netherlands Comprehensive Cancer Organization

- Statistical analysis: Ms. Driessen

- Manuscript preparation: Ms. Driessen

- Manuscript editing and review: all authors

\section{References}

[1] Incidence of non-small cell lung cancer according to 5-year age groups in the Netherlands. Netherlands Comprehensive Cancer Center. 2018; 2015 [cited Apri 9th 2018]. Available from https://www.cijfersoverkanker.nl/selecties/dataset_2 img5acb6c8c9ce65 [Internet].

[2] Postmus PE, Kerr KM, Oudkerk M, Senan S, Waller DA, Vansteenkiste J, et al. Early and locally advanced non-small-cell lung cancer (NSCLC): ESMO clinical practice guidelines for diagnosis, treatment and follow-upt. Ann Oncol 2017;28(suppl_4): iv1-iv21.

[3] Nyman J, Hallqvist A, Lund J-Å, Brustugun O-T, Bergman B, Bergström P, et al. SPACE - a randomized study of SBRT vs conventional fractionated radiotherapy in medically inoperable stage I NSCLC. Radiother Oncol 2016;121(1):1-8.

[4] Driessen EJ, Aarts MJ, Bootsma GP, van Loon JG, Janssen-Heijnen ML. Trends in treatment and relative survival among non-small cell lung Cancer patients in the Netherlands (1990-2014): disparities between younger and older patients. Lung Cancer 2017:108:198-204.

[5] Detillon DDEMA, Driessen EJM, Aarts MJ, Janssen-Heijnen MLG, van Eijck CHJ, Veen EJ. Changes in treatment patterns and survival in elderly patients with stage I nonsmall-cell lung cancer with the introduction of stereotactic body radiotherapy and video-assisted thoracic surgery. Eur J Cancer 2018;101:30-7.

[6] Verstegen NE, Lagerwaard FJ, Hashemi SMS, Dahele M, Slotman BJ, Senan S. Patterns of disease recurrence after SABR for early stage non-small-cell lung Cancer: optimizing follow-up schedules for salvage therapy. J Thorac Oncol 2015;10(8): 1195-200

[7] Chang JY, Senan S, Paul MA, Mehran RJ, Louie AV, Balter P, et al. Stereotactic ablative radiotherapy versus lobectomy for operable stage I non-small-cell lung cancer: a pooled analysis of two randomised trials. Lancet Oncol 2015;16(6):630-7.

[8] Stokes WA, Bronsert MR, Meguid RA, Blum MG, Jones BL, Koshy M, et al. Post-treatment mortality after surgery and stereotactic body radiotherapy for early-stage non-small-cell lung Cancer. J Clin Oncol 2018;36(7):642-51.

[9] Detillon DDEMA, Veen EJ. Postoperative outcome after pulmonary surgery for nonsmall cell lung Cancer in elderly patients. Ann Thorac Surg 2018;105(1):287-93.

[10] de Rijke JM, Schouten LJ, GPMt Velde, Wanders SL, Bollen ECM, Lalisang RI, et al. Influence of age, comorbidity and performance status on the choice of treatment for patients with non-small cell lung cancer; results of a population-based study. Lung Cancer 2004:46(2):233-45.

[11] Hopmans W, Zwaan L, Senan S, van der Wulp I, Damman OC, Hartemink KJ, et al. Differences between pulmonologists, thoracic surgeons and radiation oncologists in deciding on the treatment of stage I non-small cell lung cancer: a binary choice experiment. Radiother Oncol 2015;115(3):361-6.

[12] Glotzer OS, Fabian T, Chandra A, Bakhos CT. Non-small cell lung cancer therapy: safety and efficacy in the elderly. Drug Healthcare Pat Safety 2013;5:113-21.

[13] Schulkes KJG, Nguyen C, van den Bos F, van Elden LJR, Hamaker ME. Selection of patients in Ongoing clinical trials on lung Cancer. Lung 2016;194(6):967-74.

[14] WHO. Updates to the International Classification of Diseases for Oncology. 3rd ed.; 2012.

[15] Fritz A, Percy C, Jack A, Shanmugaratnam K, Sobin L, Parkin D, et al. International classification of diseases for oncology (ICD-O) - 3rd edition, 1st revision. World Health Organization; 2013.

[16] Mirsadraee S, Oswal D, Alizadeh Y, Caulo A, van Beek EJR. The 7th lung cancer TNM classification and staging system: review of the changes and implications. World J Radiol 2012;4(4):128-34

[17] Wink KCJ, van Baardwijk A, Troost EGC, De Ruysscher D. Nodal recurrence after stereotactic body radiotherapy for early stage non-small cell lung cancer: incidence and proposed risk factors. Cancer Treat Rev 2017;56:8-15.

[18] Charlson ME, Pompei P, Ales KL, MacKenzie CR. A new method of classifying prognostic comorbidity in longitudinal studies: development and validation. J Chronic Dis 1987;40(5):373-83.

[19] Schemper M, Smith TL. A note on quantifying follow-up in studies of failure time. Control Clin Trials 1996;17(4):343-6.

[20] Nelson DBMD, Lapid DJBS, Mitchell KGMD, Correa AMP, Hofstetter WLMD, Mehran RJMD, et al. Perioperative outcomes for stage I non-small cell lung Cancer: differences between men and women. Ann Thorac Surg 2018;106(5):1499-503.

[21] Oskarsdottir GN, Halldorsson $\mathrm{H}$, Sigurdsson MI, Fridriksson BM, Baldvinsson $\mathrm{K}$ Orrason AW, et al. Lobectomy for non-small cell lung carcinoma: a nationwide study of short- and long-term survival. Acta Oncol 2017;56(7):936-42.

[22] Baine MJ, Verma V, Schonewolf CA, Lin C, Simone CB. Histology significantly affects recurrence and survival following SBRT for early stage non-small cell lung cancer. Lung Cancer 2018;118:20-6.

[23] Nilsson J, Berglund A, Bergström S, Bergqvist M, Lambe M. The role of comorbidity in the management and prognosis in nonsmall cell lung cancer: a population-based study. Acta Oncol 2017;56(7):949-56.

[24] Kapadia NS, Valle LF, George JA, Jagsi R, D'Amico TA, Dexter EU, et al. Patterns of treatment and outcomes for definitive therapy of early stage non-small cell lung Cancer. Ann Thorac Surg 2017;104(6):1881-8.

[25] Hegi F, D'Souza M, Azzi M, De Ruysscher D. Comparing the outcomes of stereotactic ablative radiotherapy and non-stereotactic ablative radiotherapy definitive radiotherapy approaches to thoracic malignancy: a systematic review and meta-analysis. Clin Lung Cancer 2017;19(3):199-212.

[26] Dalwadi SM, Szeja SS, Bernicker EH, Butler EB, Teh BS, Farach AM. Practice patterns and outcomes in elderly stage I Non-Small-cell Lung Cancer: A 2004 to 2012 SEER analysis. Clin Lung Cancer 2018;19(2):e269-76.

[27] Onishi HMD, Shirato HMD, Nagata YMD, Hiraoka MMD, Fujino MMD, Gomi KMD, et al. Stereotactic body radiotherapy (SBRT) for operable stage I non-small-cell lung cancer: can SBRT be comparable to surgery? Int J Radiat Oncol Biol Phys 2011;81(5):1352-8

[28] Chen H, Laba JM, Boldt RG, Goodman CD, Palma DA, Senan S, et al. Stereotactic ablative radiation therapy versus surgery in early lung Cancer: a meta-analysis of propensity score studies. Int J Radiat Oncol Biol Phys 2018;101(1):186-94.

[29] Samuels MA, Kandula S, Koru-Sengul T, Bogart JA, Salama JK, Aridgides PD, et al. Stereotactic body radiotherapy in patients with stage I non-small-cell lung Cancer aged 75 years and older: retrospective results from a Multicenter consortium. Clin Lung Cancer 2013:14(4):446-51. 
[30] Kreinbrink P, Blumenfeld P, Tolekidis G, Sen N, Sher D, Marwaha G. Lung stereotactic body radiation therapy (SBRT) for early-stage non-small cell lung cancer in the very elderly ( $\geq 80$ years old): extremely safe and effective. Journal of Geriatric Oncology 2017;8(5):351-5.

[31] Schulkes KJG, Pouw CAM, Driessen EJM, van Elden LJR, van den Bos F, JanssenHeijnen MLG, et al. Lung Cancer in the oldest old: a nation-wide study in the Netherlands. Lung 2017;195(5):627-34.

[32] Tekatli H, van't Hof S, Nossent EJ, Dahele M, WFAR Verbakel, Slotman BJ, et al. Use of Stereotactic Ablative Radiotherapy (SABR) in non-small cell lung cancer measuring more than $5 \mathrm{~cm}$. J Thorac Oncol 2017;12(6):974-82.

[33] Sigel K, Bonomi M, Packer S, Wisnivesky J. Effect of age on survival of clinical stage I non-small-cell lung Cancer. Ann Surg Oncol 2009;16(7):1912-7.

[34] Pallis AG, Gridelli C, Wedding U, Faivre-Finn C, Veronesi G, Jaklitsch M, et al. Management of elderly patients with NSCLC; updated expert's opinion paper: EORTC elderly task force, lung Cancer group and International Society for Geriatric Oncology. Ann Oncol 2014;25(7):1270-83.

[35] Onaitis MW, Salama J. Surgery versus stereotactic body radiation therapy for operable stage I non-small cell lung cancer: can we achieve equipoise? J Thorac Cardiovasc Surg 2016;152(1):1-2.

[36] Asmis T, Ding K, Seymour L, Shepherd FA, Leighl N, Winton T, et al. Age and comorbidity as independent prognostic factors in the treatment of non-small-cell lung Cancer: a review of National Cancer Institute of Canada clinical trials group trials. J Clin Oncol 2008;26(1):54-9.
37] Deleuran T, Thomsen RW, Nørgaard M, Jacobsen JB, Rasmussen TR, Søgaard M. Comorbidity and survival of Danish lung cancer patients from 2000-2011: a population-based cohort study. Clin Epidemiol 2013;5(Suppl. 1):31-8.

[38] Mokhles S, Nuyttens JJME, de Mol M, Aerts JGJV, Maat APWM, Birim Ö, et al. Treatment selection of early stage non-small cell lung cancer: the role of the patient in clinical decision making. BMC Cancer 2018;18:79.

[39] Pallis AG, Scarci M. Are we treating enough elderly patients with early stage nonsmall cell lung cancer? Lung Cancer 2011;74(2):149-54.

[40] Wolff HB, Alberts L, Kastelijn EA, Lissenberg-Witte BI, Twisk JW, Lagerwaard FJ, et al. Differences in longitudinal health utility between stereotactic body radiation therapy and surgery in stage I non-small cell lung Cancer. J Thorac Oncol 2018;13(5): 689-98.

[41] Verstegen NE, Lagerwaard FJ, Haasbeek CJA, Slotman BJ, Senan S. Outcomes of stereotactic ablative radiotherapy following a clinical diagnosis of stage I NSCLC: comparison with a contemporaneous cohort with pathologically proven disease. Radiother Oncol 2011;101(2):250-4.

[42] Chen H, Louie AV, Boldt RG, Rodrigues GB, Palma DA, Senan S. Quality of life after stereotactic ablative radiotherapy for early-stage lung Cancer: a systematic review. Clin Lung Cancer 2016;17(5):e141-9.

[43] Shaverdian N, Wang J, Steinberg ML, Lee P. The Patient's perspective on SBRT for treatment of early-stage non-small cell lung Cancer (NSCLC). Int J Radiat Oncol Biol Phys 2015;93(3):E484-5. 